\title{
Unauthorized Mexican Workers in the United States: Recent Inflows and Possible Future Scenarios
}

Pia M. Orrenius and Madeline Zavodny

Federal Reserve Bank of Dallas

Research Department Working Paper 1701 


\title{
Unauthorized Mexican Workers in the United States: Recent Inflows and Possible Future Scenarios *
}

\author{
Pia M. Orrenius \\ Federal Reserve Bank of Dallas \\ pia.orrenius@dal.frb.org \\ Madeline Zavodny \\ Agnes Scott College \\ mzavodny@agnesscott.edu
}

January 2, 2017

\begin{abstract}
The U.S. economy has long relied on immigrant workers, many of them unauthorized, yet estimates of the inflow of unauthorized workers and the determinants of that inflow are hard to come by. This paper provides estimates of the number of newly arriving unauthorized workers from Mexico, the principal source of unauthorized immigrants to the United States, and examines how the inflow is related to U.S. and Mexico economic conditions. Our estimates suggest that annual inflows of unauthorized workers averaged about 170,000 during 1996-2014 but were much higher before the economic downturn that began in 2007. Labor market conditions in the U.S. and Mexico play key roles in this migrant flow. The models estimated here predict that annual unauthorized inflows from Mexico will be about 100,000 in the future if recent economic conditions persist, and higher if the U.S. economy booms or the Mexican economy weakens.

JEL Codes: J15, J18, J61
\end{abstract}

Keywords: Unauthorized Immigrants, Illegal Immigration, Temporary Foreign Workers

\footnotetext{
* We thank Michael Clemens and an anonymous reviewer for helpful comments and Emily Gutierrez, Sarah Greer, and Jack Wang for excellent research assistance. Madeline Zavodny thanks the Center for Global Development for support. This paper is also available as CGD Working Paper 436 (September, 2016). The views expressed here are those of the authors and do not reflect those of the Federal Reserve Bank of Dallas or the Federal Reserve System.
} 


\section{Introduction}

Unauthorized immigration is the focus of considerable attention among policy makers and the public. Beliefs that the large number of unauthorized immigrants creates adverse economic and fiscal effects underlie much of this attention. About 11 million unauthorized immigrants were present in the United States in 2014 (Passel and Cohn, 2015a; Warren, 2016). The majority of them-5.6 to 6 million — are from Mexico (Gonzalez-Barrera, 2015; Warren, 2016).

Most unauthorized immigrants move to the United States to work in the world's largest economy. Almost all are from poorer countries where they earn much less than they can earn working illegally in the United States. The large number of unauthorized immigrants from Mexico is not surprising given that, as Clemens and Hashmi (2016) note, a worker can earn \$10 a day at home, or cross the border into the United States and earn that much per hour. ${ }^{1}$ The number of unauthorized immigrants from Mexico present in the United States is more than 10 times larger than the number from any other country (National Research Council, 2013).

The difficulty of entering or staying legally in the United States is a little-understood but important contributor to unauthorized immigration. The United States grants permanent resident and temporary foreign worker visas via complicated rules, and many categories of visas are numerically capped. Almost all of the 140,000 employment-based permanent resident visas require a bachelor's degree; only 5,000 per year are currently available to low-skilled workers, who must hold a year-round job. There are also country quotas; only 25,620 permanent resident visas are available per country across all numerically capped categories each year, causing would-be immigrants from major sending countries to face lengthy delays. Mexicans who applied for family-sponsored visas more than 20 years ago are only now being admitted. ${ }^{2}$ U.S. temporary foreign worker visa programs involve complicated rules as well. The H-2A agricultural and $\mathrm{H}-2 \mathrm{~B}$ non-agricultural visa programs for low-skilled temporary or seasonal jobs are unpopular with many employers, who believe they are costly, complex, and time-consuming. Employers have instead largely turned to unauthorized workers.

One obvious way to reduce the number of unauthorized immigrants in the United States and to increase the economic gains from immigration is to expand existing visa programs or create new legal channels for workers to enter. This is particularly the case for less-educated workers from Mexico, few of whom are able to legally immigrate to the United States. This paper explores the possibility of an employment-based visa program for workers from Mexico. Focusing on Mexico, at least initially, may make sense given the large share of unauthorized immigrants from there.

If the United States were to create an employment-based visa program to enable employers to bring in less-skilled workers from Mexico, what should be the range for the number of visas? One key to the program's success would be channeling inflows of workers who would otherwise be unauthorized into a legal stream. If successfully implemented, this stream should meet

\footnotetext{
${ }^{1}$ Taking differences in the cost of living reduces this difference somewhat, of course. Clemens, Montenegro, and Pritchett (2008) estimate that the average low-skilled worker earns 2.5 times more in the United States than in Mexico when controlling for differences in the cost of living.

${ }^{2}$ See http://travel.state.gov/content/visas/en/law-and-policy/bulletin/2016/visa-bulletin-for-march-2016.html (accessed 9 March 2016).
} 
employers' needs while minimizing adverse effects on competing American workers. Setting the number of visas too low risks continued large inflows of unauthorized workers from Mexico, which would be unacceptable to many policy makers and the American public, as well as forgoing some of the benefits of immigration. ${ }^{3}$ Setting the number of visas too high risks negative effects on American workers who are substitutes for the migrant workers, both U.S. natives and earlier immigrants.

This paper examines the size of gross inflows of unauthorized workers from Mexico during 1996 to 2014 and the determinants of those inflows. The past is not necessarily a predictor of the future, but past inflows may suggest patterns that can shed light on the demand for visas and how it would respond to changes in underlying factors in the United States and Mexico. We estimate that an average of 170,000 unauthorized workers entered the United States from Mexico per year during 1996 to 2014. The number was much higher - up to 300,000 per year-when the U.S. economy, particularly the construction sector, was booming.

The estimates presented here differ from other estimates of unauthorized immigration in several respects. Our estimates are for workers, whereas estimates from other sources are for the entire population of unauthorized migrants. We focus on estimating the gross inflow, not the net inflow or the stock of unauthorized immigrants. All of these measures are of interest to policy makers, but estimates of the gross inflow are the most relevant if policymakers are designing a new worker visa program or changing an existing one. We present estimates created using several techniques, which can be viewed as giving upper and lower bounds on the inflow of unauthorized immigrant workers from Mexico.

\section{Data and Methods}

Measuring the stock or the flow of unauthorized workers from Mexico is challenging. Unauthorized immigrants are a difficult population to count since they either successfully evade detection when they enter the United States or do not leave when their visa expires. The former are, by definition, unobserved (although their number can be estimated), while the Department of Homeland Security has only very recently begun to attempt to track the latter. ${ }^{4}$

This paper estimates the gross inflow of unauthorized workers from Mexico using data from the U.S. Census Bureau, which conducts frequent large-scale population surveys that include questions about migration and labor market behavior. ${ }^{5}$ Specifically, we use data from the 1996-

\footnotetext{
${ }^{3}$ Although net migrant flows from Mexico are estimated to be negative since 2005, gross inflows are still greater than zero (Gonzalez-Barrera, 2015).

${ }^{4}$ See U.S. Department of Homeland Security (2016). "Entry/Exit Overstay Report Fiscal Year 2015.” Washington, DC: U.S. Department of Homeland Security. Available at

https://www.dhs.gov/sites/default/files/publications/FY\%2015\%20DHS $\% 20$ Entry $\% 20$ and $\% 20$ Exit $\% 20$ Overstay $\% 2$ 0Report.pdf (accessed 4 February 2016).

${ }^{5}$ We do not use any Mexican data sources to estimate the inflow of unauthorized immigrants because of those sources' limitations. The Encuesta Nacional de Ocupacion y Empleo (ENOE, or National Survey of Occupation and Employment) includes questions about recent migration history and about household members who went to live or work in another country. However, the survey cannot capture migrants when their entire household has moved to the United States. The same is true of other major Mexican surveys, such as the Mexican Census of Housing and Population and the Encuesta Nacional de al Dinámica Demográfica (ENADID, or National Survey of Population Dynamics). Over time, more entire households have left Mexico. Tighter U.S. enforcement, which makes it more difficult for family members to return home periodically to visit, has played a role in this shift, as has more drug-
} 
2004 March Current Population Survey (CPS) Annual Social and Economic Supplement and the 2005-2014 American Community Survey (ACS) to estimate the number of likely unauthorized immigrants from Mexico who entered the United States within the last year. ${ }^{6}$ A number of other studies use these data to estimate the number and characteristics of the unauthorized immigrant population (e.g., Passel and Cohn, 2015a; Gonzalez-Barrera, 2015).

These surveys do not ask respondents about their legal status. We therefore use three main methods to estimate the inflow of unauthorized immigrant workers from Mexico. The first method is to predict the legal status of new Mexican immigrant workers in the CPS and ACS based on another survey that does ask about legal status: the 2008 Survey of Income and Program Participation (SIPP). The second method is to count the number of new immigrant workers from Mexico in the CPS and ACS and subtract an estimate of the number of such workers coming legally, namely with a temporary visa. The third method involves creating simple proxies. The next sections detail how we create these estimates.

\section{Predicted legal status based on the SIPP}

The SIPP is a nationally representative panel survey of households. Households are usually surveyed multiple times over a four-year period. The most recent SIPP began in 2008. The second wave of that survey, conducted between January and April 2009, asked several questions about participants' immigration status. Specifically, it asked participants where they were born; whether they were a U.S. citizen; how they became a U.S. citizen if they were foreign born; their immigration status when they entered the United States if they were not a U.S. citizen at birth or by adoption; whether their status has since changed to permanent resident if they were not a permanent resident when they entered the United States; and when they moved to the United States. The survey also asks about demographic characteristics, labor market outcomes, and participation in various government assistance programs.

A careful examination of the SIPP concludes that it accurately captures the unauthorized immigrant population. Bachmeier, Van Hook, and Bean (2014) compare the number and characteristics of unauthorized immigrants in the SIPP to other surveys that ask about legal status and to other estimates. They conclude, "SIPP-based estimates of the characteristics of the unauthorized population compare favorably to estimates derived from other data sources and using other methods" (558).

We categorize Mexican and Central American workers aged 16-64 in the 2008 SIPP as unauthorized immigrants or not based on their responses to the questions outlined above. ${ }^{7} \mathrm{We}$ posit that immigrants are unauthorized if they say they are not a naturalized U.S. citizen, did not

related violence in Mexico. Sample size is also a concern for those surveys. The Encuesta sobre Migración en la Frontera Norte (EMIF-N, or Survey of Migration at the Northern Border) tries to count flows at busy crossing points along the U.S.-Mexico border but is not comprehensive enough to reliably estimate aggregate inflows. See National Research Council (2013) for a discussion.

${ }^{6}$ The CPS and ACS data are from, respectively, King (2010) and Ruggles et al. (2015).

${ }^{7}$ The public-use version of the 2008 SIPP combines Mexican immigrants with Central American immigrants. The public-use version also only indicates whether an individual entered the United States as a permanent resident; the confidential version of the data distinguishes between three categories of legal permanent residency, refugee/asylee status, non-immigrant status (i.e., a temporary visa), and "other." Few Mexican immigrants qualify for refugee/asylee status, and none for Temporary Protected Status. 
enter as a permanent resident, have not since become a permanent resident, moved to the United States after 1980, do not work in a government job, do not participate in a government assistance program that is typically limited to legal immigrants, and do not appear to be on a student visa. ${ }^{8}$ Several other studies use a similar approach to determine legal versus unauthorized status in the SIPP, including Bachmeier, Van Hook, and Bean (2014) and Hall, Greenman, and Farkas (2010).

Using these criteria, 46 percent of Mexican and Central American immigrant workers in the 2008 SIPP are categorized as unauthorized immigrants. This is less than other estimates of the fraction of immigrants from that region who are unauthorized. For example, estimates from the Office of Immigration Statistics indicate that about 58 percent of Mexican immigrants and at least one-half of immigrants from Central America present in the United States in 2010 were unauthorized. ${ }^{9}$ Our relatively low unauthorized share is likely due to a combination of an undersample of unauthorized immigrants in the SIPP and to deliberate misreporting by some unauthorized immigrants of their place of birth, U.S. citizenship status, or permanent resident status; the accuracy of our estimates is discussed in further detail later in the paper.

We use a probit model to estimate the relationship between whether a Mexican or Central American immigrant worker is unauthorized and a set of individual characteristics that are also available in the CPS and ACS data. Those characteristics are sex, age (5 categories), marital status (6 categories), Hispanic ethnicity, education (5 categories), current school enrollment status, industry (14 categories), place of residence (10 major states plus the rest of the United States), poverty status, family size, number of families living in the household, home ownership, age at migration and its square, and number of years since migration. ${ }^{10}$ The estimated probit coefficients are reported in Appendix Table 1.

We then take the estimated coefficients from the probit model and apply them to the CPS and ACS data. For each Mexican immigrant worker aged 16-64 in the CPS and ACS data, we predict the probability of being unauthorized and multiply that probability by the person weight. ${ }^{11}$ The sum of those weighted probabilities is our baseline estimate of the number of unauthorized

\footnotetext{
${ }^{8}$ The government assistance programs we include are Medicaid, Medicare, military health insurance, adult Social Security income, and adult Supplemental Security Income. Immigrants who entered at age 18 or older and who are currently enrolled in school full time are considered to be on a student visa and hence not likely unauthorized immigrants. We follow the "logic-based reallocation" method outlined by Bachmeier, Van Hook, and Bean (2014) to deal with imputed U.S. citizenship or legal permanent residence. If an immigrant's answer to U.S. citizenship status, entry as a permanent resident, or subsequent adjustment to permanent residence was imputed, we categorize them as unauthorized if they moved to the United States after 1980, do not work in a government job, do not participate in a government assistance program that is typically limited to legal immigrants, and do not appear to be on a student visa. We weight individuals using the person weights provided by the SIPP.

${ }^{9}$ Based on comparing the estimates in Baker and Rytina (2013) to data on the foreign-born population by region of birth in Grieco et al. (2012). The numerator for Central Americans includes only migrants from El Salvador, Guatemala, and Honduras, whereas the denominator includes all of Central America, making it an underestimate. ${ }^{10}$ The states are Arizona, California, Florida, Georgia, Illinois, New Jersey, New York, North Carolina, Texas, and Washington.

${ }^{11}$ We do not examine only Mexican immigrants who report not being a naturalized U.S. citizen because of concerns about incorrect answers to that question. Van Hook and Bachmeier (2013) estimate that, in the 2010 ACS, only 4 percent of Mexican-born men who report having entered the United States within the last five years and being a naturalized citizen actually are. They recommend not accepting at face value self-reported data on naturalized citizenship status for recent immigrants, Mexican men, and older Mexican women.
} 
Mexican workers present in the United States. Other studies that use the SIPP data to predict legal status in other surveys include Batalova, Hooker, and Capps (2014), Capps et al. (2013), and Judson (2012). ${ }^{12}$

We next estimate the inflow of new unauthorized workers from Mexico using the responses to two questions: where did a person live a year ago, and when did a person come to live in the United States. For both questions, we examine Mexicans who have migrated to the United States within the last year. ${ }^{13}$ We report separate estimates based on each question.

\section{Residual method}

The second main way we estimate the inflow of new unauthorized workers from Mexico is a variant of the widely used residual method. The residual method involves calculating the total number of immigrants and then subtracting off the estimated number of legal immigrants, which is based on administrative data on lawful entries after accounting for deaths and return migration among those entrants. ${ }^{14}$ The remainder is the estimated number of unauthorized immigrants. This method can be used for either stocks or flows (the number of immigrants who entered during a given period).

The residual method estimates are based on counting the total number of newly arrived Mexican workers in the CPS and ACS and then subtracting off an estimate of the number of Mexicans who received a temporary worker visa - both high- and low-skilled. ${ }^{15}$ The count of newly arrived Mexican workers is created in the two ways described above except that we do not impute a probability of being unauthorized. Instead, we count the number of newly arrived Mexican workers in the CPS and ACS data, adjust for undercount, and then subtract an estimate of the number of workers who have a temporary worker visa. This method assumes that no newly arrived Mexican workers entered with permanent resident status; it also assumes that everyone who received a temporary worker visa entered the United States. ${ }^{16}$

\footnotetext{
${ }^{12}$ Caponi and Plesca (2014) take a similar approach by using data on new legal permanent residents from the New Immigrant Survey to predict whether new entrants in the ACS are legal.

13 The Current Population Survey reports year of entry in categories. To create a one-year estimate based on year of entry, we divide the raw estimate for the most recent period of entry by the number of months in that period and then multiply by 12 . The ACS does not report survey month. To create a one-year estimate, we multiply the raw estimate created based on year of entry by $2 / 3$. This implicitly assumes that one-half of ACS participants are interviewed in the first half of the year.

${ }^{14}$ See Warren and Warren (2013) for an excellent discussion and cites to early and recent studies using the residual method.

${ }^{15}$ We subtract off the number of people with temporary worker visas (H-1B, H-2A, H2-B, J-1, L-1, O-1, O-2, and TN visas) from Mexico, according to U.S. Department of State data (http://travel.state.gov/content/visas/en/law-andpolicy/statistics/non-immigrant-visas.html). We scale down the number of temporary worker visas by two-thirds to account for the likelihood of being a repeat visa holder instead of a new arrival. The data are for fiscal years and are not available for 1996, so we use 1997 data for that year.

16 The U.S. Department of Homeland Security does not publish data on the number of LPRs adjusting status versus newly arriving by country. We believe the share who are new arrivals is likely to be very low for Mexican workers because of the decades-long queue for most family-sponsored immigrants from Mexico; most are likely to be already living in the United States and adjusting status.
} 


\section{Simple proxies for unauthorized immigrants}

Finally, we show two simple proxies for the inflow of new unauthorized workers from Mexico: the number of newly arrived Mexican workers aged 16-64 in the CPS and ACS who have at most a high school diploma ("less-educated"), and the number of Mexican workers aged 16-64 who do not report being a veteran, receiving a government benefit that requires having legal status, or working for the government or in a white-collar occupation that requires having a license ("logic-based").

A number of other studies use similar groups as proxies for unauthorized immigrants. Studies that use less-educated Hispanic immigrants as a proxy for unauthorized immigrants include Amuedo-Dorantes and Bansak (2012, 2014), Bohn, Lofstrom, and Raphael (2014), and Orrenius and Zavodny $(2015,2016)$. This measure has the advantage of simplicity but mistakenly counts less-educated legal immigrants as unauthorized and more-educated unauthorized immigrants as legal. Nonetheless, it is highly correlated with measures of migrant inflows, such as Border Patrol apprehensions along the U.S.-Mexico border. Borjas (2016) constructs a logic-based measure of unauthorized immigrants similar to ours. ${ }^{17}$ This measure is also simple to create and correlates well with estimates based on the residual method.

\section{Adjusting for undercount}

We believe the estimates using the above methods are conservative estimates of the number of unauthorized workers entering from Mexico for several reasons.

First, the surveys we use are generally believed to undercount immigrants, particularly unauthorized ones and those who recently arrived. Immigrants may be unwilling to cooperate with a government survey, especially if they are in the United States illegally. Further, unauthorized immigrants change residences and phone numbers relatively frequently, making it harder for a survey to reach them. The estimated undercount of unauthorized immigrants in the ACS is generally believed to be in the range of 10 to 20 percent. ${ }^{18}$

The surveys we use are also unlikely to capture very short-term or recent migrants. These surveys aim to capture the U.S.-resident population. They are unlikely to include unauthorized workers who cross over for a short period of time and then return home, either voluntarily or because they are deported, or who recently arrived and are not certain they will stay and become

\footnotetext{
${ }^{17}$ Unlike Borjas, we do not condition on not living in public housing, receiving rental subsidies, or receiving public health insurance because these measures are not available for some years of the ACS data. We also do not condition on reported U.S. citizenship status (or spouse's reported status) because of concern that Mexican immigrants deliberately misreport being U.S. citizens (see footnote 11). It is particularly unlikely that new entrants are U.S. citizens.

${ }^{18}$ Warren and Warren (2013) assume an undercount rate of 20 percent for the most recently arrived cohort of unauthorized residents in the 2010 ACS. Warren (2014) assumes an undercount of 12 percent among unauthorized immigrants who arrived in the last five years. Van Hook et al. (2014) estimate that the coverage error rate among prime-aged Mexican immigrants as a whole, not just recent unauthorized immigrants, in the 2010 ACS is -13 percent to 12 percent for women and -2 percent to 17 percent for men; negative numbers indicate an overcount of Mexican migrants in the ACS because the weights were based on older population estimates that did not take the recent drop in Mexican migration into account. Van Hook et al. note that coverage error rates are almost certainly higher for unauthorized immigrants. DHS assumes an undercount of 10 percent in its estimates (Baker and Rytina, 2013). Hanson (2006) also provides a good discussion of undercount rates.
} 
U.S. residents. Whether such migrants should be considered U.S. residents is unclear, but if they are hired by U.S. employers, they are U.S. workers, even if only briefly.

Relatedly, our estimates undercount circular migrants, those who frequently move back and forth between Mexico and the United States. Ideally, we could be able to count those migrants each year they enter the United States to work. Our estimates based on year of migration miss circular migrants who entered within the last year if they report the first year they entered rather than the most recent year. ${ }^{19}$ Our estimates based on place of residence last year miss those who were in the United States a year ago, returned to Mexico, and then re-entered the United States again this year.

Misreporting of place of birth is another source of downward bias in our estimates. We assume that respondents' answers in the CPS and ACS about their birthplace are truthful. This may not be the case because of social desirability bias, the tendency of survey respondents to provide answers they feel are more socially acceptable.

Finally, our estimates of the migrant flow are not likely to capture immigrant workers who overstay or otherwise violate the terms of a visa and are therefore newly unauthorized workers, although not new entrants to the United States. Visa overstayers are generally believed to account for about one-third to one-half of all unauthorized immigrants in the United States (Rosenblum and Hipsman, 2016). This share may have increased over time as U.S. border enforcement has intensified. It is not known what share of unauthorized immigrants from Mexico are visa overstayers. Similarly, the share of immigrants legally present in the United States on a non-work visa who work illegally is not known, either overall or specifically for Mexican immigrants.

Because of these concerns, we adjust our estimates upwards by 20 percent. We believe this is a conservative adjustment for newly arrived Mexican workers who are unauthorized. We do not compute standard errors and confidence intervals for our estimates. We instead present estimates using several methods, as explained above. We round all numbers to the nearest 10,000 . We caution against interpreting small year-to-year differences as meaningful because of measurement error in our estimates. We particularly note it that can be difficult to distinguish population changes from methodological changes when comparing across the CPS and ACS surveys (and sometimes across years within a survey). ${ }^{20}$

\section{Recent Trends in Unauthorized Immigration from Mexico}

Before discussing our estimates of new workers, which are flow measures, we present baseline estimates of the total number of unauthorized workers from Mexico, a stock measure. These estimates are created by applying the SIPP probability model to the CPS and ACS data on all Mexican immigrant workers. Figure 1 shows our estimates. The number of unauthorized workers from Mexico generally rose during the late 1990s and early 2000s and then fell after 2007.

The decline in the number of unauthorized workers from Mexico since 2007 is due to several factors. The first is changes in economic conditions. The Great Recession of 2007-2009 and

\footnotetext{
${ }^{19}$ Redstone and Massey (2004) discuss the difficulties of interpreting the year of migration question.

${ }^{20}$ See the appendix in Gonzalez-Barrera (2015) and references therein for a discussion.
} 
subsequent slow economic recovery in the United States weakened the jobs magnet. The recession began with a widespread collapse of the U.S. construction sector, which hit Mexican migrant workers particularly hard (Orrenius and Zavodny, 2009). Meanwhile, the downturn was sharp but short-lived in Mexico, and the recovery there was stronger because there was no housing bust like in the United States. Second, immigration enforcement increased in the United States. Stricter enforcement of federal immigration laws, especially at the U.S.-Mexico border but also in the interior, reduced entries and increased deportations (Orrenius, 2014). Some states adopted laws that made it more difficult for unauthorized immigrants to live and work in those states (e.g., Bohn, Lofstrom, and Raphael, 2014; Orrenius and Zavodny, 2016). Finally, a dramatic drop in the birth rate in Mexico a generation ago led to a smaller cohort of potential migrants (Hanson and McIntosh, 2009).

Consistent with our estimates, other estimates indicate that net migration from Mexico-the number of legal and illegal entrants less the number of return migrants - has been near zero or even negative in recent years. The total Mexican-born population in the United States has been falling since 2007, with the number of arrivals declining and the number of migrants returning to Mexico rising (Gonzalez-Barrera, 2015). ${ }^{21}$ Population growth was slowing even before the Great Recession: Chiquiar and Salcedo (2013) estimate that net migration inflows (legal and illegal) from Mexico averaged 277,000 per year during 2000-2007, down from 466,000 annually during 1990-2000.

Figure 2 compares our estimates of the total number of unauthorized immigrant workers from Mexico to estimates of the total unauthorized Mexican immigrant population from the Pew Research Center (Gonzales-Barrera, 2015) and the Department of Homeland Security (Baker and Rytina, 2013). ${ }^{22}$ The numbers show similar trends; our numbers are, of course, lower since we estimate the number of unauthorized workers, not the total unauthorized population. All of the series show a general increase through 2006 or 2007 and then a decline. The decline is more pronounced in our estimates and Pew Research Center's than in the Department of Homeland Security's, which are older estimates. The share of unauthorized Mexican immigrants in the labor force appears to have declined over time, as evidenced by the growing gap between the number of workers and the total population of unauthorized Mexican immigrants.

Figure 3 shows our estimates of the number of newly arrived unauthorized workers from Mexico derived from applying the SIPP probability model to the CPS and ACS data on new arrivals (based on year of entry or place last year). The cyclical pattern evident in the total number of unauthorized workers is even more pronounced in the number of new entrants. Estimates based on year of entry tend to be lower than those based on place last year. The estimates based on year of entry are also less volatile during the late 1990s than those based on place last year; we suspect this is because year of entry is reported in categories in the CPS, which smooths the data. $^{23}$

\footnotetext{
${ }^{21}$ Some studies conclude that return migration to Mexico did not rise during the Great Recession; see, for example, Rendall, Brownell, and Kups (2011).

${ }^{22}$ Gonzalez-Barrera (2015) reports estimates for 1995, 2000, and 2005-2014. Estimates for 1996-1999 and 20012004 are linear interpolations.

${ }^{23}$ See footnote 13 .
} 
Figure 4 shows estimates based on the residual method, where we calculate the total number of newly arrived workers from Mexico and subtract an estimate of the number of entrants on temporary worker visas. These numbers are initially higher than those based on the SIPP imputation but are lower after 2008. This reflects an increase in the number of temporary worker visas issued to Mexicans over time, particularly during 2012-2014.

Figure 5 shows our simple proxies for the number of new unauthorized workers from Mexico. All four measures show similar trends, particularly during the 2000s. Using less-educated Mexican immigrant workers who were not living in the United States a year ago tends to give the lowest estimates, while the logic-based imputation using Mexican immigrant workers who entered the United States during the last year tends to give the highest estimates.

Table 1 reports the average number of new unauthorized workers from Mexico from each estimation method for three time periods: 1996-2014 as a whole; 1996-2006, a period when the U.S. economy was relatively strong; and 2007-2014, the period of the Great Recession and its aftermath. The average across our estimates is more than twice as high during 1996-2006 than during 2007-2014. ${ }^{24}$

As a final look at how well our estimates capture inflows, we compare them with apprehensions of illicit border crossers from Mexico. Figure 6 shows the average across our estimates of new unauthorized workers from Mexico together with U.S. Border Patrol apprehensions of illegal aliens from Mexico along the Southwest border. ${ }^{25}$ The two measures show similar trends, particularly after 2000 .

\section{Determinants of Unauthorized Worker Inflows from Mexico}

We next examine how economic conditions in the United States and Mexico affect the inflow of unauthorized workers. The figures presented above indicate that inflows are cyclical, but which economic variables should policy makers turn to if they want to predict inflows? Do Mexican or U.S. economic conditions matter more?

To answer these questions, we estimate Cochrane-Orcutt AR(1) regressions in which the dependent variable is the log of the average of our estimates of inflows. Table 2 presents the estimated coefficients; we report four different specifications because of concerns that some of the measures of economic conditions are collinear. We measure U.S. economic conditions using the real average wage, construction permits, and total employment; we measure Mexican

\footnotetext{
${ }^{24}$ Gonzalez-Barrera (2015) similarly estimates that Mexican inflows fell by more than one-half from 1995-2000 to 2005-2010. She estimates that about 870,000 Mexicans immigrated to the United States during 2009 to 2014, or about 174,000 per year. This accords with our average estimate of 100,000 per year during 2007 to 2014 if 50 to 60 percent of Mexican immigrants are workers.

${ }^{25}$ The apprehensions data are from https://www.cbp.gov/sites/default/files/documents/BP\%20Total\%20Apps\%2C\%20Mexico\%2C\%20OTM\%20FY20 00-FY2015.pdf for 2000-2014 and https://www.cbp.gov/sites/default/files/documents/BP\%20Southwest\%20Border\%20Sector\%20A for 1996-1999; the latter data are all nationalities, not just Mexicans; Mexicans were the vast majority of apprehended entrants during that period. The apprehensions data are by fiscal year.
} 
economic conditions using the real average wage and total employment. ${ }^{26}$ All economic variables are logged. We include construction permits for the United States because of the large number of unauthorized immigrants working in that sector. The measures of economic conditions are lagged one year in order to use information that policy makers should have in hand. ${ }^{27}$

The regressions also include U.S. Border Patrol staffing along the Southwest border to control for the difficulty or cost of crossing the border, and cohort size to control for labor supply shocks. ${ }^{28}$ Cohort size is measured as the number of births 15-19 years ago in each country. The regressions also include a linear time trend and its square. Caution is warranted in interpreting the regression results given the short time series available. A time-series regression rule of thumb suggests that a minimum of 30 observations is required for standard distributional assumptions to hold.

Before turning to the results, it is worth briefly discussing why we examine the role of supplyside factors, namely Mexican economic conditions and demographics, and border enforcement. After all, visa programs for foreign workers are aimed at alleviating labor shortages in the United States, not at accommodating all potential migrants. This might suggest that only demand-side variables - U.S. wages, employment, and construction permits - are relevant. But it is important to control for supply-side factors and border enforcement, both of which affect labor supply and, hence, wages and the number of potential migrants. Moreover, supply-side variables are likely correlated with demand-side factors and need to be controlled for in order to obtain accurate measures of demand-side effects on migration.

The results indicate that economic conditions in both the United States and Mexico affect unauthorized worker inflows. Higher wages in the United States attract more unauthorized immigrant workers, with a 1 percent increase in the average wage boosting average inflows by 8 to 14 percent, depending on the specification used. This is a very large sensitivity, presumably because average wages were flat or falling in the United States during much of the period that we examine. An increase in the average wage in Mexico reduces migration, with a 1 percent increase reducing outflows by 3 to 4 percent. ${ }^{29}$ Construction permits are not significantly related

\footnotetext{
${ }^{26}$ The U.S. wage is the annual average of the weekly wage from the BLS payroll employment survey and is deflated using the CPI-W; U.S. construction permits are annual permits issued for single family privately owned structures; U.S. employment is seasonally adjusted total nonfarm December payroll employment from the BLS. The Mexican real wage is from OECD measures of annual wages for full-time workers and is deflated using the Mexican CPI; Mexico total employment is also from OECD measures of average annual employment (formal and informal sectors).

${ }^{27}$ In addition, significance levels are lower if we use contemporaneous measures of economic conditions, suggesting that migrants make their decision based on economic conditions in the recent past.

${ }^{28}$ Border Patrol staffing is from https://www.cbp.gov/sites/default/files/documents/BP\%20Staffing\%20FY1992FY2015.pdf. Relative cohort size is calculated using data on Mexican births from the World Development Indicators (http://databank.worldbank.org/data/reports.aspx?source=health-nutrition-and-population-statistics:-populationestimates-and-projections\#) and on U.S.-born high school dropouts as calculated from the CPS and ACS data.

${ }^{29}$ Wage volatility has lessened considerably in Mexico over time. This may make pull factors more important than push ones. Hanson and Spilimbergo (1999) note that economic conditions in Mexico as a push factor appear to have dominated U.S. economic conditions as a pull factor during 1968-1996, which is unusual in studies of migration behavior. We find evidence that both push and pull factors matter, but pull factors appear to have a bigger effect.
} 
to migration flows in the specifications shown here. ${ }^{30}$ An increase in total employment in the United States boosts inflows when other measures of U.S. economic conditions are not included in the regression. Changes in total employment in Mexico do not significantly affect unauthorized outflows from there. In results not shown here, we find little evidence that U.S. employment or output in construction or agriculture is related to flows; U.S. manufacturing employment is positively related to inflows. Also in results not shown here, we do not find evidence of a positive relationship between the peso-to-dollar exchange rate and unauthorized immigration, either in real or nominal terms.

The results in Table 2 also show that increased border enforcement reduces the number of new unauthorized workers, as expected. A larger cohort of U.S. teenagers reduces the number of new unauthorized workers from Mexico when U.S. and Mexican average wages are used to control for economic conditions. This negative relationship makes sense if U.S. teens fill jobs that otherwise might be filled by unauthorized immigrants. Meanwhile, a larger cohort of Mexican teenagers boosts out-migration from there; their entry into the labor force may push down their relative wage, which raises the incentive to migrate.

We do not examine several other demographic variables that are likely to affect migration patterns, namely average age and educational attainment. Rising average age and educational attainment in the United States have boosted the demand for low-skilled foreign-born workers. Notably, the share of U.S.-born workers without a high school diploma fell from more than onehalf in 1950 to less than 5 percent in 2010 (Zavodny and Jacoby, 2013). Unauthorized immigrants fill jobs for which native-born workers are in short supply. Meanwhile, falling birth rates, rising average age, and increasing educational attainment in Mexico have reduced the supply of low-skilled workers from there. Our data, which cover only a 19-year period, are not ideal for examining demographic factors like age and education, which typically change slowly and smoothly.

\section{Scenarios for Future Flows}

The gross inflow of unauthorized Mexican workers in the medium or long run is difficult to predict. As Lowell (2014) notes, almost all forecasts failed to predict the drop in Mexican immigrant inflows during the mid-2000s, and it is difficult to reconcile the timing of the decline with the U.S. economic downturn, which came later. Further caveats include that we examine past relationships here, which may not hold in the future, and we are basing our predictions on only 19 data points, a relatively short time series.

With those caveats in mind, our results predict an annual inflow of about 100,000 migrants in 2029. This prediction is based on the assumption that real wages and employment continue to grow at their average annual rates from 2010-14 and U.S. border enforcement and construction permits remain at their 2014 levels. ${ }^{31}$ Stronger U.S. economic growth would boost predicted

\footnotetext{
${ }^{30}$ Construction permits are positively related to unauthorized inflows if the time trend variables are not included in the second specification shown in Table 2.

${ }^{31}$ Our predictions also incorporate the level of Mexican births 15-19 years earlier. We do not incorporate the U.S. cohort size variable or the time trend and its square in the predictions. Although the theoretical justification for the U.S. cohort size variable is sound, the coefficient is not statistically significant in any specifications that include U.S. demand-side variables, such as construction permits or employment. Moreover, the coefficient is unstable, changing sign from negative to positive depending on the model. Given its erratic yet outsized influence, we exclude
} 
unauthorized inflows. If real wages rose by 1 percent a year (versus their average of 0.4 percent from 2010-14) and employment by 2.5 percent a year (versus 1.8 percent), predicted inflows would be about 300,000 per year. Weaker Mexican economic growth would also boost predicted unauthorized inflows, although the effects are smaller than for robust U.S. economic growth. If Mexican real wages were flat over the next 15 years (versus their average of 0.7 percent growth from 2010-14) and Mexican employment grew at 1 percent a year (versus 1.7 percent), predicted unauthorized inflows would be about 160,000 per year.

\section{Policy Considerations}

Unauthorized immigrants play a non-trivial role in the U.S. economy, accounting for about 5 percent of the labor force. They play a particularly important role in agriculture, where they account for 16 percent of workers; construction, at 12 percent; and the leisure and hospitality sector, at 7 percent (Passel and Cohn, 2015b). Curtailing unauthorized immigration without creating a legal means for employers to hire foreign workers would create economic strain on these sectors.

Importantly, unauthorized immigration is more responsive to market forces than is legal immigration. As Hanson (2007) notes, unauthorized immigration "provides U.S. businesses with the types of workers they want, when they want them, and where they want them" (5). Unauthorized immigration is a fast, flexible source of workers, which benefits the U.S. economy by reducing bottlenecks and fostering economic growth. Most legal immigration programs in the United States, in contrast, involve fixed caps, long wait times, and considerable bureaucracy.

Visa programs that aim to channel unauthorized immigration into legal streams and boost the economic gains from immigration will work best if they adopt the features of unauthorized immigration that result in economic benefits. These would include automatically adjusting to changes in economic conditions in the United States and Mexico (or other source countries) that affect labor demand and supply. It would also mean allowing employers, not government bureaucracies, to choose the workers they want, and allowing workers to easily move jobs. Unauthorized immigrants are a spot market, which is attractive to many employers. A visa program that replicates this aspect will entice employers to use it instead of hiring unauthorized workers, particularly if coupled with more worksite enforcement.

It is vital to consider immigrants already in the United States, not just potential immigrants in their home countries, when designing a new visa program. Before bringing in new low-skilled workers legally, it makes sense to create ways for unauthorized immigrants already here to receive legal permission to work, either temporarily or permanently. Unauthorized immigrants currently make up about 5 percent of the U.S. labor force, and giving them legal status would likely boost that share. In addition to their sheer size, immigrants who are already here are likely to be more productive since they are more familiar with U.S. customs and markets, have U.S. work experience and speak better English. Hence, some of the visas in a new program aimed at

it from these projections. Similarly, we do not include the time trend variables since they are not statistically significant in the specifications reported in Table 2 (with one exception) yet have a large effect on the predictions. It is not clear what variable underlies the concave trend given that the models estimated here control for the key drivers of emigration. Without knowing what variable underlies that trend, there is no reason to expect it to continue to hold in the future. The predictions are smaller if the time trend and U.S. cohort size variables are incorporated. 
low-skilled immigrants could be made available to those already here illegally. Alternatively, this group could be treated separately. Existing unauthorized workers may not fit neatly into a new worker program since they are not good candidates for temporary status. New workers may be expected to circulate and leave their families behind, while existing unauthorized workers are unlikely to do either so since many of them have already settled in the U.S. and have U.S.-born children. Intensified border enforcement, among other factors, has increased immigrants' length of stay, converted circular migrants into permanent ones, and prompted entire families to move to the U.S.

Concerns about the current H-2 programs and the Bracero program, which ran from 1942 until 1964 , offer a number of additional lessons for a temporary foreign worker program to succeed. ${ }^{32}$ Workers are particularly vulnerable to abuse, and downward pressure on wages and working conditions is greater, when workers are trapped with one employer, as is the case under current temporary foreign worker programs. Relatedly, it should not be cheaper for firms to bring in foreign workers than to hire American workers. Employers must pay market wages and payroll taxes, plus a visa fee. Temporary foreign workers need to be covered by employer-provided health insurance requirements and other labor standards on the same terms as other workers. Finally, a program should not withhold a portion of pay until workers return home or retire unless policy makers are confident that workers will be able to receive it when eligible. The U.S. government should hold any such funds (often called "bonds" by economists), not employers or foreign governments.

A binational program with Mexico would be a logical pilot, but it would make sense to expand the program to other countries that are major sources of low-skilled immigrant workers. The importance of Mexico as a source of unauthorized workers in the U.S. has been falling over time. Indeed, the majority of people apprehended trying to illegally cross the Mexico-U.S. border in fiscal year 2014 were not Mexican nationals. Ongoing instability in Central America combined with higher birth rates there than in Mexico mean that region is likely to continue to comprise a sizable and growing share of unauthorized migrants in the United States.

\section{Conclusion}

The number of unauthorized workers entering from Mexico in recent years is perhaps the best guide when setting the number of employment-based visas for a program designed for lessskilled workers from there. Our estimates indicate the need for a large-scale program if policy makers want to successfully channel unauthorized inflows into legal temporary worker programs and increase the economic benefits of immigration. That said, setting a fixed number of visas independent of the U.S. business cycle would be ill advised since inflows are highly cyclical. Our estimates suggest that inflows before the Great Recession were more than twice their level since the downturn.

The number of Mexican immigrants entering the United States has declined sharply in recent years. It is too early to know if this marks a long-term secular trend or a temporary shift. There has been little convergence between U.S. and Mexican wages in recent decades, so one of the fundamental drivers of migration remains in place (Gandolfi, Halliday, and Robertson, 2015).

\footnotetext{
32 The Bracero program was created to allow employers to bring in farm laborers from Mexico to alleviate worker shortages during World War II.
} 
That said, Mexico's population growth has slowed and its cohort of young workers ages 15-24 is currently peaking (at 23 million) and will soon begin to shrink. ${ }^{33}$ Partly as a result, other areas, particularly Central America, are growing sources of unauthorized immigrants (Massey, Durand, and Pren, 2014). An employment-based visa program with only Mexico would reduce the number of unauthorized workers in the United States but would be unlikely to entirely eliminate unauthorized migration.

Forecasting future demand for visas is a difficult exercise given the sizable swings in number of new unauthorized workers in recent years and uncertainty regarding future U.S. and Mexican economic conditions. Designing a viable visa program requires creating one that does not require regular tinkering. The best way to do this is to rely on market-based measures, such as flexible caps and visa auctions, where employers buy visas or permits to sponsor foreign workers (Lowell, 2014).

The end of the Bracero program marked the beginning of large-scale unauthorized immigration from Mexico (Hanson, 2006). Reducing unauthorized immigration without major dislocations to the U.S. economy will require expanding existing visa programs or creating new ones. Doing so would bring several benefits, not least of all to immigrants, who would no longer risk their lives trying to cross the border and then be limited to living in the shadows in the United States. It would also benefit American workers by leveling the playing field between them and formerly unauthorized workers. It's time for a new approach to immigration policy, beginning with an employment-based visa program for Mexican workers.

${ }^{33}$ Based on UN medium variant population projections. 


\section{References}

Amuedo-Dorantes, Catalina, and Cynthia Bansak (2012). "The Labor Market Impact of Mandated Employment Verification Systems.” American Economic Review: Papers \& Proceedings 103: 543-8.

Amuedo-Dorantes, Catalina, and Cynthia Bansak (2014). "Employment Verification Mandates and the Labor Market Outcomes of Likely Unauthorized and Native Workers." Contemporary Economic Policy 32: 671-680.

Bachmeier, James D., Jennifer Van Hook, and Frank D. Bean (2014). "Can We Measure Immigrants' Legal Status? Lessons from Two U.S. Surveys." International Migration Review 48: 538-566.

Baker, Brian, and Nancy Rytina (2013). "Estimates of the Unauthorized Immigrant Population Residing in the United States: January 2012." Washington, DC: Office of Immigration Statistics, U.S. Department of Homeland Security. Available at https://www.dhs.gov/sites/default/files/publications/ois ill pe 2012 2.pdf (accessed 31 March 2016).

Batalova, Jeanne, Sarah Hooker, and Randy Capps (2014). "DACA at the Two-Year Mark: A National and State Profile of Youth Eligible and Applying for Deferred Action." Washington, DC: Migration Policy Institute. Available online at http://www.migrationpolicy.org/research/daca-two-year-mark-national-and-state-profile-youtheligible-and-applying-deferred-action (accessed 9 March 2016).

Bohn, Sarah, Magnus Lofstrom, and Steven Raphael (2014) "Did the 2007 Legal Arizona Workers Act Reduce the State's Unauthorized Immigrant Population?" Review of Economics and Statistics 96: 258-269.

Borjas, George J. (2016). “The Labor Supply of Undocumented Immigrants.” Cambridge, MA: National Bureau of Economic Research working paper no. 22102.

Caponi, Vincenzo, and Miana Plesca (2014). "Empirical Characteristics of Legal and Illegal Immigrants in the USA." Journal of Population Economics 27: 923-960.

Capps, Randy, Michael Fix, Jennifer Van Hook, and James D. Bachmeier (2013). “A Demographic, Socioeconomic, and Health Coverage Profile of Unauthorized Immigrants in the United States." Washington, DC: Migration Policy Institute. Available online at http://www.migrationpolicy.org/research/demographic-socioeconomic-and-health-coverageprofile-unauthorized-immigrants-united-states (accessed 9 March 2016).

Chiquiar, Daniel, and Alejandrina Salcedo (2013). "Mexican Migration to the United States: Underlying Economic Factors and Possible Scenarios for Future Flows." Washington, DC: Migration Policy Institute. Available at http://www.migrationpolicy.org/research/mexican- 
migration-united-states-underlying-economic-factors-and-possible-scenarios-future (accessed 2 April 2016).

Clemens, Michael, and Nabil Hashmi (2016). "Modernizing US Migration Policy for Domestic and Development Gains," Washington, DC: Center for Global Development. Available at http://www.cgdev.org/sites/default/files/whw-migration.pdf (accessed 9 March 2016).

Clemens, Michael, Claudio E. Montenegro, and Lant Pritchett (2008). "The Place Premium: Wage Differences for Identical Workers across the US Border." Washington, DC: Center for Global Development. Available at http://www.cgdev.org/sites/default/files/16352_file_CMP_place_premium_148.pdf (accessed 4 April 2016).

Gandolfi, Davide, Timothy Halliday, and Raymond Robertson (2015). "Trade, Migration, and the Place Premium: Mexico and the United States." Washington, DC: Center for Global Development. Available at http://www.cgdev.org/sites/default/files/CGD-Working-Paper-396Beyond-Fence-Gandolfi-Halliday-Robertson 0.pdf (accessed 10 March 2016).

Gonzalez-Barrera, Ana (2015). "More Mexicans Leaving Than Coming to the U.S." Washington, DC: Pew Research Center. Available at http://www.pewhispanic.org/files/2015/11/2015-11-19_mexican-immigration_FINAL.pdf (accessed 19 November 2015).

Grieco, Elizabeth M., et al. (2012). "The Foreign-Born Population in the United States: 2010." Washington, DC: U.S. Census Bureau. Available at http://www.census.gov/content/dam/Census/library/publications/2012/acs/acs-19.pdf (accessed 31 March 2016).

Hall, Matthew, Emily Greenman, and George Farkas (2010). "Legal Status and Wage Disparities for Mexican Immigrants.” Social Forces 89: 491-514.

Hanson, Gordon H. (2006). "Illegal Migration from Mexico to the United States." Journal of Economic Literature 44: 869-924.

Hanson, Gordon H. (2007). "The Economic Logic of Illegal Immigration.” New York: Council on Foreign Relations. Available online at http://www.cfr.org/immigration/economic-logicillegal-immigration/p12969 (accessed 4 April 2016).

Hanson, Gordon H., and Craig McIntosh (2009). "The Demography of Mexican Migration to the United States.” American Economic Review Papers \& Proceedings 99: 22-27.

Hanson, Gordon H., and Antonio Spilimbergo (1999). "Illegal Immigration, Border Enforcement, and Relative Wages: Evidence from Apprehensions at the U.S.-Mexico Border." American Economic Review 89: 1337-1357. 
Judson, Dean H. (2012). "Imputing the Legal Status of Foreign-Born Persons on Surveys: Two New Approaches.” Mimeo, State Health Access Data Assistance Center, University of Minnesota.

King, Miriam, Steven Ruggles, J. Trent Alexander, Sarah Flood, Katie Genadek, Matthew B. Schroeder, Brandon Trampe, and Rebecca Vick (2010). Integrated Public Use Microdata Series, Current Population Survey: Version 3.0. [Machine-readable database]. Minneapolis, MN: Minnesota Population Center.

Lowell, B. Lindsay (2014). "Managing Immigration: A Review of Some Past Projections." Migration Letters 11: 33-42.

Massey, Douglas S., Jorge Durand, and Karen A. Pren (2014). "Explaining Undocumented Migration to the U.S.” International Migration Review 48: 1028-1061.

National Research Council (2013). Options for Estimating Illegal Entries at the U.S.-Mexico Border. Washington, DC: National Academies Press.

Orrenius, Pia M. (2014). "Enforcement and Illegal Migration.” IZA World of Labor 81: 1-10. Available online at http://wol.iza.org/articles/enforcement-and-illegal-migration (accessed 2 April 2016).

Orrenius, Pia M., and Madeline Zavodny (2009). "Tied to the Business Cycle: How Immigrants Fare in Good and Bad Economic Times." Washington, DC: Migration Policy Institute. Available at http://www.migrationpolicy.org/research/tied-business-cycle-how-immigrants-fare-good-andbad-economic-times (accessed 2 April 2016).

Orrenius, Pia M., and Madeline Zavodny (2015). "The Impact of E-Verify Mandates on Labor Market Outcomes.” Southern Economic Journal 81: 947-959.

Orrenius, Pia M., and Madeline Zavodny (2016). "Do State Work Eligibility Verification Laws Reduce Unauthorized Immigration?” IZA Journal of Migration 5: 1-17.

Passel, Jeffrey S., and D’Vera Cohn (2015a). "Unauthorized Immigrant Population Stable for Half a Decade." Washington, DC: Pew Research Center. Available at http://www.pewresearch.org/fact-tank/2015/07/22/unauthorized-immigrant-population-stablefor-half-a-decade/ (accessed 2 March 2016).

Passel, Jeffrey S., and D’Vera Cohn (2015b). "Share of Unauthorized Immigrant Workers in Production, Construction Jobs Falls Since 2007." Washington, DC: Pew Research Center. Available at http://www.pewhispanic.org/files/2015/03/2015-03-26 unauthorized-immigrantspassel-testimony_REPORT.pdf (accessed 4 April 2016).

Redstone, Ilana, and Douglas S. Massey (2004). "Coming to Stay: An Analysis of the U.S. Census Question on Immigrants' Year of Arrival.” Demography 41: 721-738. 
Rendall, Michael S., Peter Brownell, and Sarah Kups (2011). "Declining Return Migration From the United States to Mexico in the Late-2000s Recession: A Research Note." Demography 48: 1049-1058.

Rosenblum, Marc R., and Faye Hipsman (2016). "Border Metrics: How to Effectively Measure Border Security and Immigration Control.” Washington, DC: Migration Policy Institute. Available at http://www.migrationpolicy.org/research/border-metrics-how-effectively-measureborder-security-and-immigration-control (accessed April 6, 2016).

Ruggles, Steven, Katie Genadek, Ronald Goeken, Josiah Grover, and Matthew Sobek (2015). Integrated Public Use Microdata Series: Version 6.0 [Machine-readable database]. Minneapolis: University of Minnesota.

Van Hook, Jennifer, and James D. Bachmeier (2013). "How Well Does the American Community Survey Count Naturalized Citizens?” Demographic Research 29: 1-32.

Van Hook, Jennifer, Frank D. Bean, James D. Bachmeier, and Catherine Tucker (2014). "Recent Trends in Coverage of the Mexican-Born Population of the United States: Results From Applying Multiple Methods Across Time.” Demography 51: 699-726.

Warren, Robert (2014). "Democratizing Data about Unauthorized Residents in the United States: Estimates and Public-Use Data, 2010 to 2013." Journal on Migration and Human Security 2: 305-328.

Warren, Robert (2016). "US Undocumented Population Drops Below 11 Million in 2014, with Continued Declines in the Mexican Undocumented Population." Journal on Migration and Human Security 4: 1-15.

Warren, Robert, and John R. Warren (2013). "Unauthorized Immigration to the United States: Annual Estimates and Components of Change, by State, 1990 to 2010.” International Migration Review 47: 296-329.

Zavodny, Madeline, and Tamar Jacoby (2013). "Filling the Gap: Less-skilled Immigration in a Changing Economy." Washington, DC: ImmigrationWorks and American Enterprise Institute. Available online at https://www.aei.org/wp-content/uploads/2013/06/-zavodny-filling-the-gapimmigration-report_140631709214.pdf (accessed 4 April 2016). 

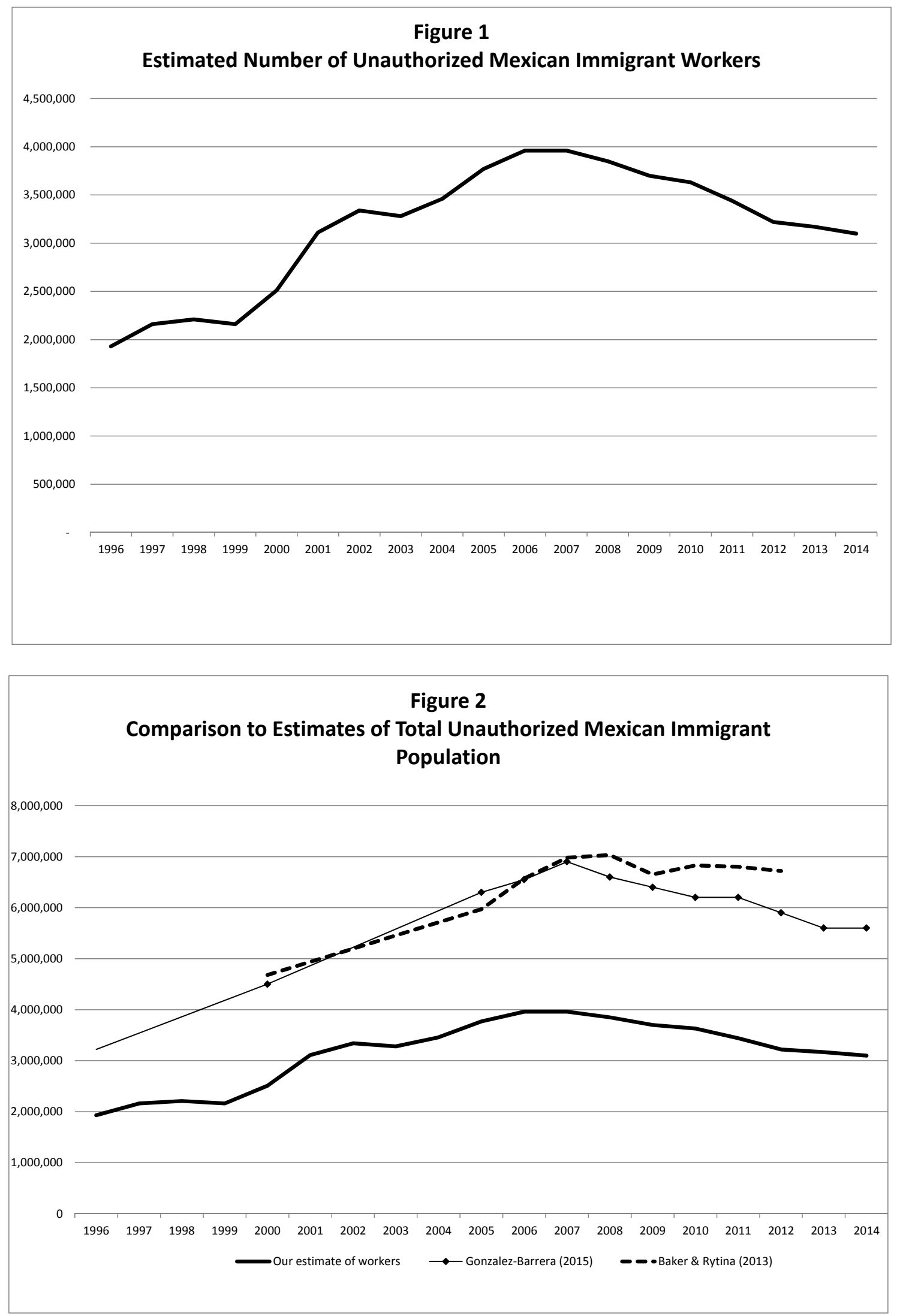


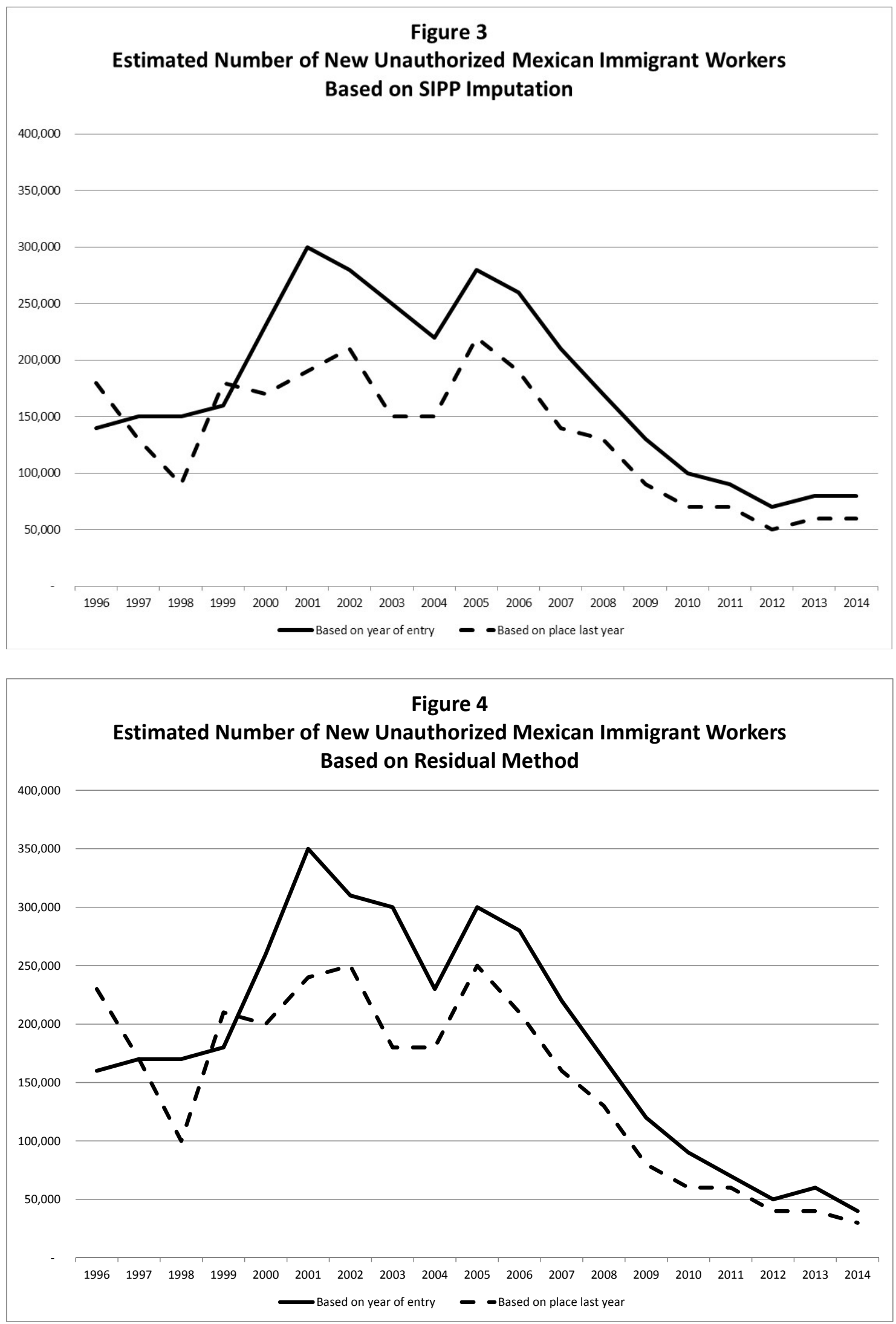



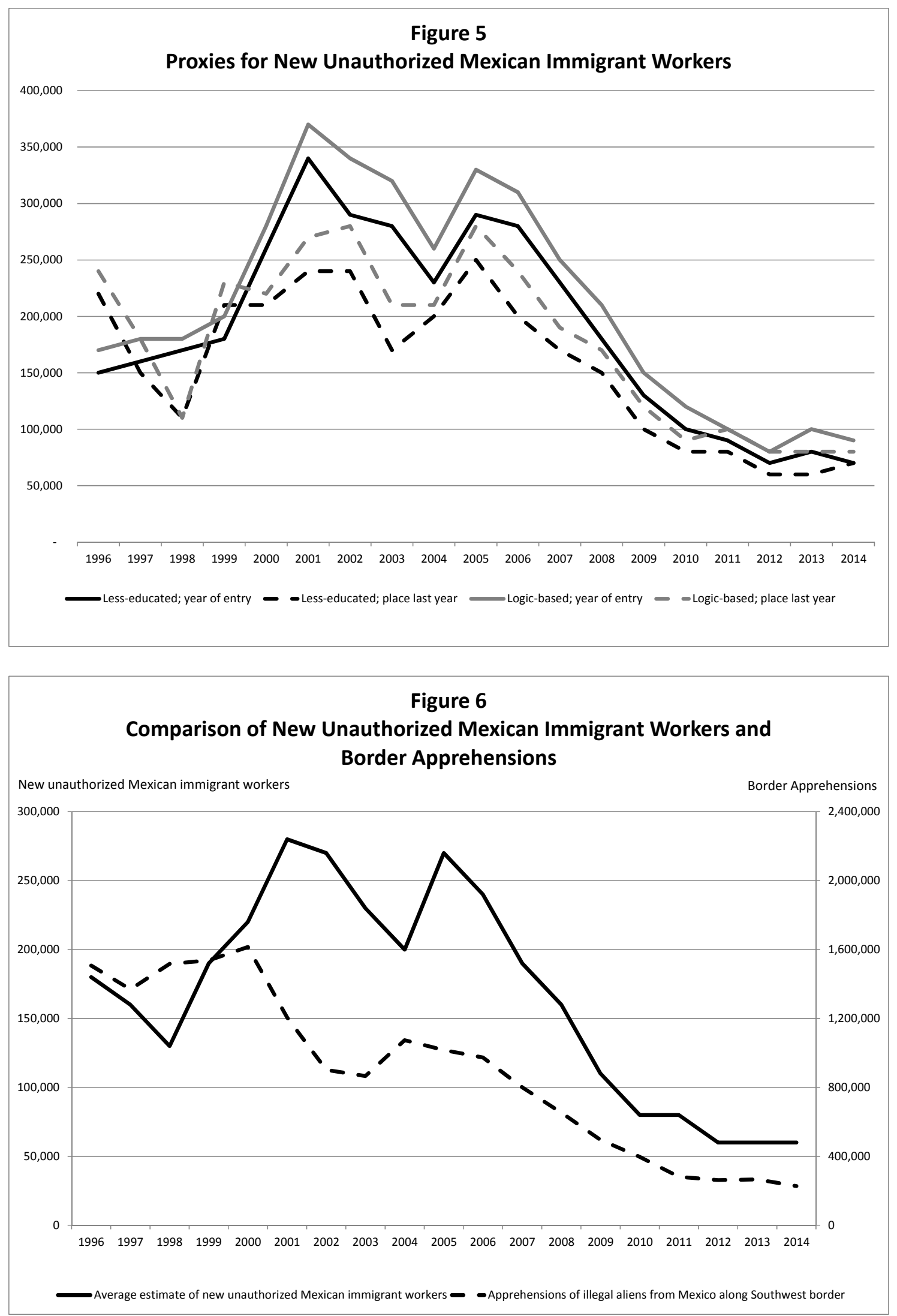


\begin{tabular}{lccc}
$\begin{array}{l}\text { Table } 1 \\
\text { Average Estimated Number of New Unauthorized Mexican Immigrant Worker }\end{array}$ & \multicolumn{1}{l}{ Im } \\
Estimation method & $1996-2014$ & $1996-2006$ & $2007-2014$ \\
\hline SIPP imputation, year of entry & 170,000 & 210,000 & 110,000 \\
SIPP imputation, place last year & 130,000 & 160,000 & 80,000 \\
Residual method, year of entry & 180,000 & 240,000 & 100,000 \\
Residual method, place last year & 140,000 & 200,000 & 70,000 \\
Less-educated proxy, year of entry & 180,000 & 230,000 & 110,000 \\
Less-educated proxy, place last year & 150,000 & 200,000 & 90,000 \\
Logic-based proxy, year of entry & 210,000 & 260,000 & 130,000 \\
Logic-based proxy, place last year & 170,000 & 220,000 & 110,000 \\
\hline Average across all methods & 170,000 & 220,000 & 100,000 \\
\hline
\end{tabular}

Source: See text. 
Table 2

Determinants of the Number of New Unauthorized Workers from Mexico

\begin{tabular}{|c|c|c|c|c|}
\hline & $(1)$ & $(2)$ & $(3)$ & $(4)$ \\
\hline Lagged U.S. average wage & $\begin{array}{l}14.177 * * * \\
(1.821)\end{array}$ & $\begin{array}{l}14.218 * * * \\
(1.871)\end{array}$ & -- & $\begin{array}{l}8.467 * * \\
(3.568)\end{array}$ \\
\hline Lagged Mexican average wage & $\begin{array}{l}-3.135^{* *} \\
(1.214)\end{array}$ & $\begin{array}{l}-3.319 * \\
(1.517)\end{array}$ & -- & $\begin{array}{l}-3.990 * * \\
(1.490)\end{array}$ \\
\hline Lagged U.S. construction permits & -- & $\begin{array}{l}-0.047 \\
(0.228)\end{array}$ & -- & $\begin{array}{l}-0.521 \\
(0.363)\end{array}$ \\
\hline Lagged U.S. total employment & -- & -- & $\begin{array}{l}9.602 * * \\
(3.192)\end{array}$ & $\begin{array}{c}6.963 \\
(3.900)\end{array}$ \\
\hline Lagged Mexican total employment & -- & -- & $\begin{array}{l}-6.172 \\
(6.253)\end{array}$ & $\begin{array}{l}-5.954 \\
(4.438)\end{array}$ \\
\hline Border enforcement & $\begin{array}{l}-1.105 * * * \\
(0.261)\end{array}$ & $\begin{array}{l}-1.166^{* *} \\
(0.395)\end{array}$ & $\begin{array}{l}-1.450 * * \\
(0.644)\end{array}$ & $\begin{array}{l}-2.253 * * \\
(0.815)\end{array}$ \\
\hline U.S. births $15-19$ years ago & $\begin{array}{c}-17.424 * * \\
(6.537)\end{array}$ & $\begin{array}{l}-20.469 \\
(16.368)\end{array}$ & $\begin{array}{c}11.499 \\
(25.418)\end{array}$ & $\begin{array}{l}-28.323 \\
(16.366)\end{array}$ \\
\hline Mexican births $15-19$ years ago & $\begin{array}{l}21.323 * * * \\
(3.460)\end{array}$ & $\begin{array}{l}22.396^{* * *} \\
(6.426)\end{array}$ & $\begin{array}{l}-3.625 \\
(6.738)\end{array}$ & $\begin{array}{l}18.707 * * \\
(6.463)\end{array}$ \\
\hline Time trend & $\begin{array}{c}0.068 \\
(0.148)\end{array}$ & $\begin{array}{c}0.129 \\
(0.334)\end{array}$ & $\begin{array}{c}0.135 \\
(0.585)\end{array}$ & $\begin{array}{c}0.694 \\
(0.443)\end{array}$ \\
\hline Time trend squared & $\begin{array}{l}-0.008 \\
(0.005)\end{array}$ & $\begin{array}{l}-0.010 \\
(0.011)\end{array}$ & $\begin{array}{l}-0.004 \\
(0.016)\end{array}$ & $\begin{array}{l}-0.024 * \\
(0.012)\end{array}$ \\
\hline Rho & -0.483 & -0.504 & -0.159 & -0.510 \\
\hline Durbin-Watson statistic & 2.675 & 2.665 & 2.366 & 2.785 \\
\hline Adjusted R-squared & 0.992 & 0.992 & 0.966 & 0.994 \\
\hline Number of observations & 18 & 18 & 18 & 18 \\
\hline
\end{tabular}

Note: Shown are estimated coefficients from an AR(1) regression of unauthorized immigration of workers on economic conditions, border enforcement, birth cohorts, and time trends. Standard errors in parentheses. Asterisks denote statistical significance at the 0.1, 0.05, and 0.01 levels. 


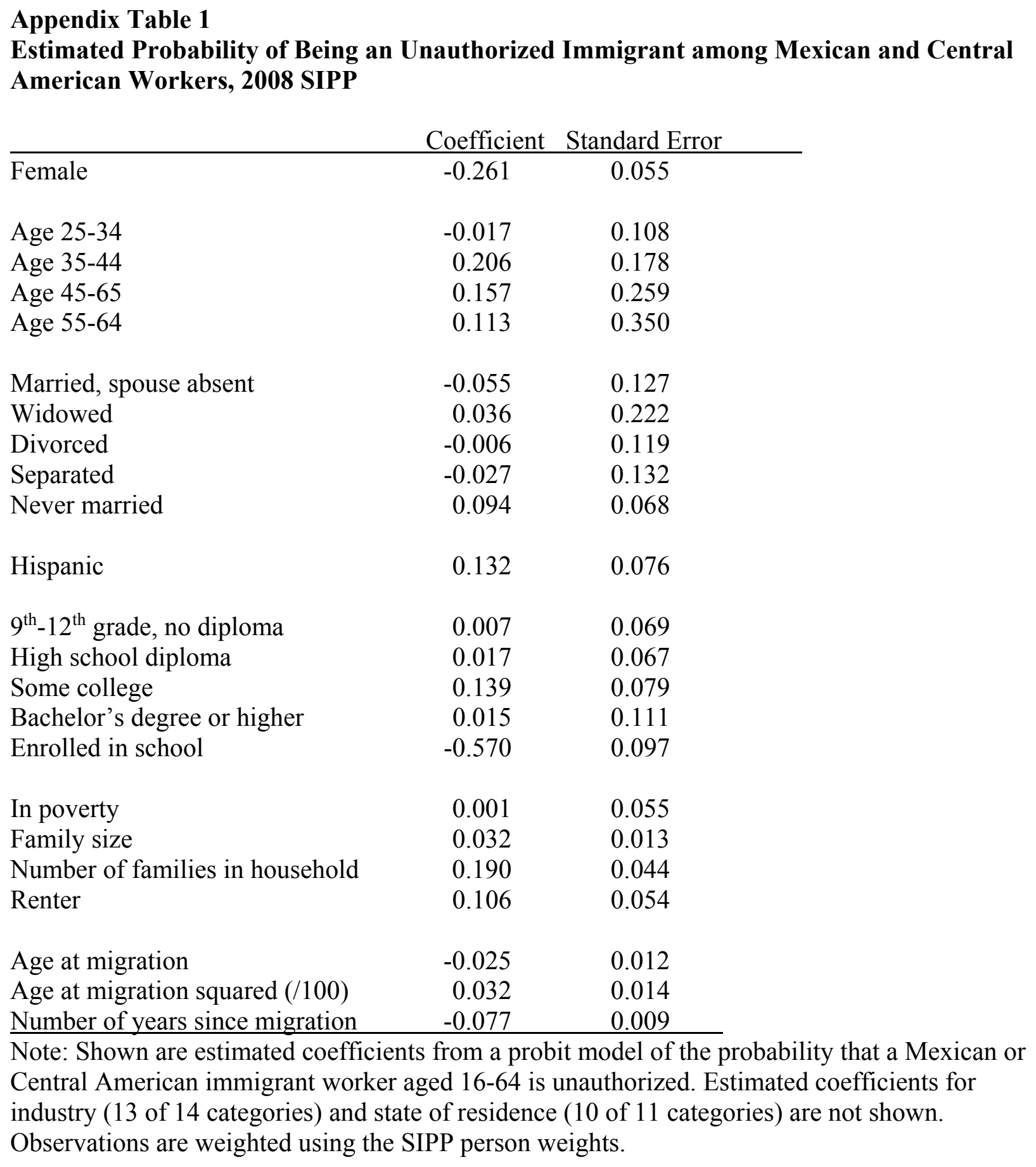

